\title{
Avoiding Bias in the Study of Populism
}

\author{
Paris Aslanidis ${ }^{1,2}$
}

Received: 30 April 2017/Accepted: 8 June 2017/Published online: 28 June 2017

(C) Fudan University and Springer Nature Singapore Pte Ltd. 2017

\begin{abstract}
The comparative study of populism has produced a wide spectrum of scholarship that covers different regions and historical periods. However, and despite significant breakthroughs in conceptualization and methodology, the process of scientific cumulation is hampered by the unyielding persistence of several misconceptions around the nature of populism, even in the face of repeated refutation by empirical developments. In this paper, I single out and discuss three main problems in the literature: the regional bias, the policy bias, and the normative bias. I argue that to protect the study of populism from the increasing threat of conceptual dilution due to sensationalist punditry and partisan scholarship, analysts should (a) avoid generalizing from region-specific perspectives; (b) remain skeptical of any association of populism with economic policy; and (c) refrain from exaggerating populism's impact on democratic institutions.
\end{abstract}

Keywords Populism $\cdot$ Discourse $\cdot$ European politics $\cdot$ American politics $\cdot$ Latin American politics

\section{Introduction to the Concept}

Considerable academic resources have been invested in the study of populism, yet the term remains contested. What exactly is populism? How do we identify it? Is it good or bad for democracy? Analysts disagree widely over these basic questions, earning populism an embarrassing position in the hierarchy of

Paris Aslanidis

paris.aslanidis@yale.edu

1 Department of Political Science, Yale University, New Haven, CT, USA

2 Hellenic Studies Program, MacMillan Center, Yale University, Henry R. Luce Hall, Room 242, 34 Hillhouse Avenue, New Haven, CT 06520-8206, USA 
political terms boasting conceptual rigor and operational consistency. At the same time, since its inception, populism has undergone significant conceptual stretching. Every cohort of scholars has expressed deep frustration with either "social scientists of the world [that] have mounted the hobby horse of 'populism' and ridden off rapidly in all directions" (Tindall 1972, p. 510) or with the "habit of branding as 'populist' everything from Bruce Springsteen to Rush Limbaugh to loose-fitting cotton trousers" (Kazin 1998, p. 5).

However, as Woods (2014; also, this special volume) argues, some progress is visible during the last decades. A comprehensive assessment is outside the scope of this article, but it seems that a level of convergence is forming around understanding populism as a specific type of political discourse (Aslanidis 2016a; Canovan 2005; Hawkins 2010; Kazin 1998; Laclau 2005; Müller 2016; Stavrakakis and Katsambekis 2014). Most schools of thought would today concede that populism is best operationalized as a political language that emphasizes a fundamental divide between People and elites over the issue of lawful political sovereignty, upholding the primacy of the former and accusing the latter of attempting to capture social, political, and economic institutions for their narrow interests. Scholarly controversy resumes unabated at a secondary front, where dispute revolves around whether populism is "mere" discourse or if populist discourse is a simple appendage of a more defining behavior such as the adoption of expansive economic policies (Edwards 2010), a political ideology (Mudde 2004), the exercise of unbridled topdown leadership (Roberts 2015), a distinct form of political representation (Caramani 2017), an electoral strategy (Bonikowski and Gidron 2016), or a specific style of doing politics (Moffitt 2016). ${ }^{1}$

It should be granted that some of these disputes unfold over minor technicalities that fail to undercut a broader level of agreement. Yet, while this is encouraging, progress remains precarious due to the persistence of redundant theories and a tendency to overstate populism's normative implications. Conceptual dilution is also amplified by the haphazard use of the concept by journalists and political commentators for sensationalist aims, especially in the aftermath of political episodes such as Brexit and the election of US President Trump that have been associated with a purported populist revolt at a global scale.

To achieve further scientific cumulation, students of populism must therefore practice vigilance against unyielding misconceptions that continue to inform a significant part of contemporary scholarship. The surviving biases are broken down into three main types: (a) the regional bias is at work when certain perspectives that only befit region-specific manifestations of populism are erroneously promoted to defining properties of supposedly general applicability; American scholars who equate populism with the People's Party, Latin American scholars who associate it with charismatic leaders enjoying mass electoral support, and Europeans who attach populism exclusively to the far right, are discussed in the first section; (b) the policy bias, where populism is reduced to an economic recipe that purportedly wreaks havoc on national economies, is discussed in the second section; (c) the third and final section analyzes the

\footnotetext{
1 The list is not exhaustive.
} 
normative bias, which relates to partisan assessments of populism's impact on democracy, with the aim to denigrate ideological adversaries or celebrate favorites.

\section{The Regional Bias}

Populism has a long history in several corners of the world, yet three specific regions have received disproportionate attention. In the United States, analysts of various disciplines argue that, even prior to the emergence of the People's Party, populism has permeated domestic politics, coloring both left-wing and right-wing phenomena (Kazin 1998; Formisano 2008). In the southern part of the American continent, Juan Peron provided the exemplary case of populist leadership in mid1940s Argentina, to be copied by several leaders during the post-war decades, turning Latin America into a hotbed of populist politics. Europe is the third region with a long populist record. Jean-Marie Le Pen established the far right Front National in 1972 France, providing a blueprint for several right-wing populists who continue to gather support in Western European states to this day.

This rich collection of populist episodes-spanning three populous geographic regions and several decades of political mobilization-allows us to examine patterns of political behavior unobservable to our earlier peers. Surprisingly, the literature has largely failed to take full advantage of this comparative potential (Rovira Kaltwasser 2012). Most contributions remain empirically confined to the comfort zones of their authors-those regions or national case studies they have studied in-depth or experienced first-hand. This should not prima facie affect the conceptualization of populism in a negative manner; after all, case studies are important for social science and regional studies do constitute comparative projects. However, failing to encompass the full spectrum of populist politics when generalizing from particulars will inevitably lead to errors. By stipulating features for populism that only pertain to specific settings and are unable to travel further, scholars exhibit a regional bias, effectively treating their familiar cases as ideal types. This, in turn, can lead us to inaccurately relegate nonfamiliar cases to diminished subtypes or to altogether exclude them from classification on idiosyncratic grounds, producing a set of false negatives.

The regional bias is not particularly prevalent in the US, yet experts of the People's Party do provide a case in point. For many of them, populism (preferably with a capital P) denotes the history and activity of that particular group of people that started with the Farmers' Alliance, coalesced with the Knights of Labor and other organizations into the People's Party, and ended up in fusion with the Democratic Party under William Jennings Bryan in 1896 (Pollack 1962). Affinity to the history of the People's Party is promoted into the ultimate yardstick; anything that deviates from the paradigm is not considered a "real" manifestation of populism. Even those who do entertain a wider relevance for the concept will only label a subsequent phenomenon as populist if its lineage can be somehow traced back to the original Populists. ${ }^{2}$

\footnotetext{
${ }^{2}$ Compare, for instance, the arguments in Postel (2012a) on the Tea Party to those in Postel (2012b) on Occupy Wall Street.
} 
Contrary to the US, where the ideal type is a grassroots movement that never made it to power, Latin American populism immediately connotes powerful individuals who won elections to subsequently rule as Presidents of their nations. Figures such as Chavez, Peron, Morales, Correa, Vargas, Fujimori, Menem, and the Kirchners, comprise the subject matter. The bias in this region forms as a tendency to treat "personalistic leadership" and "mass mobilization" as defining features of populism, continuing an intellectual tradition that harks back to the father of Latin American populist scholarship, Torcuato di Tella, who argued early on that populism is "based on the support of broad masses of the population, but does not derive its main power from the autonomous organizational structures of those group" (Di Tella 1965, p. 425).

Adhering to this dominant view, Levitsky and Loxton (2013, p. 110) argue that populists are outsiders who "mobilize mass support via anti-establishment appeals" by establishing a "personalistic linkage to voters, circumventing parties and other forms of institutional mediation". As a corollary, the possibility of grassroots populism is dismissed, and the concept is treated as an exclusively top-down phenomenon that mobilizes the masses through "dominant personalities who control the channels, rhythms, and organizational forms of social mobilization" (Roberts 2015, pp. 681-2). This "charismatic bond between political leaders and mass followers" (Roberts 2012, p. x), the "hierarchical relationship between a personalist leader and masses of devoted followers" (Weyland 2012, p. 201), is unequivocally seen as the common core of all populist episodes in the region's history. The leader's withdrawal would signal the end of the populist project since his rule is almost unchallengeable within a party that has associated its fate with the charisma of its captain (Horowitz 2012). ${ }^{3}$

The unconditional conceptual primacy assigned to populist leadership by Latin American scholars is particularly bewildering if one considers populism's original empirical manifestations. The personalistic element was absent or at least unremarkable both in the US Populists and the narodniki movement in tsarist Russia, those nineteenth-century grassroots movements generally treated in the literature as the main forebearers of populism (Canovan 2005; Taggart 2000; Woods, this special issue). Charismatic leadership is also a marginal topic in numerous populist episodes we have come across since then. Populist grassroots movements such as the Tea Party, Occupy Wall Street, or the European indignados, either failed to rely on explicit leadership or openly dismissed the desirability of acquiring one (Aslanidis 2016b; Gerbaudo 2017). At the level of institutionalized politics, several established populist parties either lack an undisputed "charismatic" leader or have undergone changes in leadership without losing appeal. The German AfD, the Danish People's Party, the Norwegian People's Party, the Swiss SVP, the FPÖ in Austria, the FN in France, the Lega Nord in Italy, and the Peronist Party in Argentina, are all instances where this "logic of personalism" (Weyland 2013) fails to apply. The recent transfers of power from Chavez to Maduro in Venezuela and

\footnotetext{
3 It is interesting to note that the Latin American conceptualization would render the new French President, Emmanuel Macron, as the uber-populist of our times.
} 
from Correa to Moreno in Ecuador also constitute evidence of the continuity of populism, irrespective of specific leaders.

This is not, of course, to say that leadership is trivial for populist politics. It simply goes to indicate that leadership is equally relevant for all types of political mobilization, and that assigning ultimate primacy to this feature without comparison to a control group can lead to erroneous classifications. Moreover, scholars of Latin American populism, in their uncompromising devotion to personalistic leadership as a defining feature, fail to acknowledge the influence of institutional peculiarities in the region. The countries they study feature presidential governing systems where executive power inevitably ends up in the hands of a single person. Accustomed to a habitat replete with "white swans," these scholars are tempted to stipulate a direct association. However, a cursory glance at the European habitat, where multiparty, parliamentary systems are the norm and "black swans"-like those indicated in the previous paragraph-are plenty, should suffice to overcome this misconception.

The comparison with Europe highlights the second element that cannot travel outside the Latin American region: the stipulation of a "mass following" for the leader. Populist presidents in Latin America are supported by the majority of voters (that is after all, how they manage to win elections), but in Europe, this is rarely the case. There, analysts labor over populist parties that enjoy limited, even meager electoral influence over society. A showing of over 5\% in national polls usually leads researchers to consider a party as "successful" and incorporate it into their datasets (Minkenberg 2013); others adopt even lower thresholds. For instance, political parties covered in Mudde's (2007) highly influential Populist Radical Right Parties in Europe, commanded an average electoral support of $12.9 \% .^{4}$ In an updated version of the dataset (Mudde 2013), the average drops further to $9.6 \% .^{5}$

Taken at face value, the reasoning that populism is "a question of who gains public office and how they govern" (Conniff 2012, p. 2) and that populists are leaders "who had charismatic relationships with mass followings and who won elections regularly" (ibid., p. 7), inevitably turns Europe and the US into regions of marginal experience with populism. Yet, while their electoral performance figures hardly signify anything close to "mass mobilization", dozens of European parties are classified as populist in the literature. ${ }^{6}$ The Latin American paradigm unduly restricts populism to leaders who have actually won power, rendering the dependent variable the exclusive source for case selection: instances of failed populism become non-sensical. Pushing the argument a bit further, a party or a leader that mobilizes voters for several years before managing to win office should not be classified as populist until the day they actually win power. But, did we really have to wait until January 2006 to label Evo Morales a populist or until November

\footnotetext{
4 At the time of publication, and measuring their best performance in any national election during their careers. Source: Table 2.1, p. 44 in Mudde (2007). Final calculations my own.

5 Source: Table 1, p.3 in Mudde (2013). Final calculations my own. The reduced figure compared to 2007 is mainly due to an enlarged dataset.

6 After all, as Rovira Kaltwasser (2012) indicates in his own criticism of this bias, multi-class "mass mobilization" would also apply to Christian Democratic and Social Democratic parties in Europe, in previous decades.
} 
2016 to do the same for Donald Trump? Or should we refrain from labeling Beppe Grillo a populist until his party wins the next Italian election?

Nevertheless, American scholars face strong competition in their propensity to succumb to the regional bias by their peers on the other side of the Atlantic. The European scholarship on populism has contributed its own distinctive brand: an ingrained association of populism with the far right (Moffitt 2016; Stavrakakis et al. 2017). If Juan Peron was the inspiration for academic bias in Latin America, JeanMarie Le Pen was the culprit for Europe ${ }^{7}$; and if left-wing populist leaders are usually in the crosshairs of Latin American scholarship, it is actors on the far right that attract attention in Europe. Xenophobic right-wing parties emerged in the 70s and $80 \mathrm{~s}$ as a reaction to the influx of immigrants from former colonial territories. Leading to the fall of the Iron Curtain in 1989-90 and in its immediate aftermath, new waves of immigration hit most countries of the region. Starting with Le Pen's Front National in France, a number of new parties emerged to supply an electoral option to citizens who wanted to protest against these developments. Xenophobia and even racism were core values of these actors, leading many scholars and opinion-makers to fear the return of the specter of fascism over Europe, even if these parties commanded little support. The study of the far right became a booming industry across European universities, and competition among academics vying for space on such a narrow field fostered conceptual innovation, but also occasioned a fair level of conceptual stretching.

Ignazi (2003) and Carter (2005) credit Hans-Georg Betz with the introduction of populism into mainstream scholarship on Western European far right parties. While it was not the first work to stipulate this association in European circles, ${ }^{8}$ Betz's (1994) Radical Right-Wing Populism in Western Europe ultimately mainstreamed the generalization that populist parties overlap with the extreme right. Betz fused together socioeconomic values that were distasteful to a modern, liberal audience into a mix that effectively rendered its original ingredients (right-wing ideology, radicalism, populism) indistinguishable. "Generally," he wrote,

"the majority of radical right-wing populist parties are radical in their rejection of the established socio-cultural and socio-political system and their advocacy of individual achievement, a free market, and a drastic reduction of the role of the state without, however, openly questioning the legitimacy of democracy in general. They are right-wing first in their rejection of individual and social equality and of political projects that seek to achieve it; second in their opposition to the social integration of marginalized groups; and third in their appeal to xenophobia, if not overt racism and anti-Semitism. They are populist in their unscrupulous use and instrumentalization of diffuse public sentiments of anxiety and disenchantment and their appeal to the common man and his allegedly superior common sense" (Betz 1994, p. 4).

\footnotetext{
${ }^{7}$ European scholars of populism also tend to forget that the first populist to ever win power in the continent in the post-war era was Andreas Papandreou, a radical left-winger who ruled Greece for more than a decade (Pappas 2016).

${ }^{8}$ Pierre- André Taguieff was a pioneer in this respect, especially in francophone circles (see Jäger 2017).
} 
He next cautioned the audience of the threat these radical right-wing populist parties posed for European democracies:

"Recent electoral trends illustrate the dramatic rise, diffusion, and expansion of radical right-wing populist support in Western Europe. During the past several years most of these parties have been able to expand and multiply both votes and parliamentary representation, thus threatening to render the formation of governments increasingly difficult" (Betz 1994, p. 4). ${ }^{9}$

By extension, xenophobia was promoted to a necessary dimension of European populism. This idea was solidified with Kitschelt's (1995) The Radical Right in Western Europe, in which Betz is rightly criticized for subsuming all extreme right parties under the populist label (Kitschelt 1995, p. 89), yet it is maintained that "populist antistatist parties" are firmly positioned at the far end of the political spectrum (along with fascist, welfare chauvinist, and new radical right parties), even if they are qualified as the "furthest removed from the fascist legacy" (Kitschelt 1995, p. 31).

Paul Taggart followed suit in 2000 with an equally influential book titled Populism, where he proceeded to (re)coin the term "new populism", a "contemporary form of populism that emerged, primarily but not exclusively in Western Europe, in the last part of the twentieth century" (Taggart 2000, p. 73). New populism, a phenomenon that "has been advocated by a number of parties on the far right of the political spectrum" (p. 73) centers on issues such as "taxation, immigration and nationalism or regionalism" (p. 75). In countries such as France, Austria, and Germany, according to Taggart (2000, p. 77) "new populism draws on an explicitly racist and nationalist agenda".

Later, several experts became skeptical of painting the whole family of radical right-wing parties as "populist" and voiced their reservations (e.g., Ignazi 2003; Carter 2005; Minkenberg 2015), but the vast majority of European scholars congregated around this versatile concept and applied it widely in their publications. Betz (2002, p. 206) may have sensed the limitations of the promiscuous application of his work when he subsequently proclaimed that "radical right-wing populist parties are, above all, anti-immigration parties," but the gears had already been set in motion, and populism became a media sensation. Eventually, the same parties that until the mid-90s were unproblematically studied as radical and/or extreme right were re-baptized as populist, taking on a new life and multiplying their academic paper trail. Things quickly blurred into "an almost exclusive identification of populism with the extreme Right" (Meny and Surel 2002, p. 4).

Cas Mudde, another scholar of the European extreme right, was more cautious in incorporating populism into his work. In his widely read book, he also argued in favor of using populism as a qualification for radical right parties, yet opted for the label "populist radical right parties" (Mudde 2007) rather than Betz's established "radical right populist parties". His rationale was that, in the old formulation, the primary term is populism and "radical right" is used as an epithet to indicate ideological emphasis. His own "populist radical right parties", on the other hand,

\footnotetext{
9 See also Betz (1990), Betz (1993).
} 
would connote a populist subgroup of the radical right genus. "Given that nativism, not populism, is the ultimate core feature of the ideology of this party family, radical right should be the primary term in the concept" (Mudde 2007, p. 26). In his view then, nativism, authoritarianism, and populism, formed the conceptual triad that defined the populist radical right, which meant that "while all populist radical rightists are nationalists, not all nationalists are populist radical rightists" (Mudde 2007, pp. 30-1).

However carefully populism was situated in this context, its operationalization remained vague and its extension was widely open to idiosyncratic interpretation, rendering the lines between populist and non-populist radical-right parties very hard to discern. " "Othering" in the form of excluding immigrants, foreigners, indigenous populations, sexual minorities, and other groups, from the authentic body of "the people" became for many a central tenet of populism (e.g., Wear 2008). In quantitative studies, anti-immigration was promoted to a defining feature of populism (e.g., Jagers and Walgrave 2007) and populism was even employed as a proxy variable for radical-right voter support (e.g., Norris 2005). In a characteristic example of populism's mutation into an ornament of the far right, Inglehart and Norris (2016) recently adopted Mudde's (2007) framework but curiously proceeded to explain it as advancing a view of populism that has "three core features: antiestablishment, authoritarianism, and nativism" (p. 6). For Inglehart and Norris (2016), populists "characteristically display authoritarian leanings" (p. 7), emphasize "nativism or xenophobic nationalism" (p. 7) and favor "mono-culturalism over multiculturalism" (p. 7). In other words, the "populist radical right" lost populism as a defining element of its intension, yet its extension-and branding-remained remarkably unscathed.

From a simple accompanying variable of extreme right groups, populism has been promoted to a necessary dimension and an uncontested label of the European far right without adequate conceptual justification. The vast empirical area where populism does not overlap with xenophobia or racism-even within the European continent-was lost from attention. Prior to the mid-90s, populism was rarely if ever discussed in conjunction with the European far right (e.g., Falter and Schumann 1988; Harris 1990; Husbands 1981; Ignazi 1992; von Beyme 1988); nowadays, its identification with radical and extreme right parties is total and retroactively applied to all prior manifestations. This, again, is not to say that certain far right parties in Europe do not illustrate populist elements. The European regional bias is not necessarily about the general relationship of the far right with populism since in some cases an osmosis is well established. The bias is inserted by exaggerating populism's classificatory capacity and by generalizing from particulars without taking into account the larger picture.

A logician would understand the regional bias as a typical non sequitur. Scholars study cases that fit their regional stereotype of populism, failing to incorporate control groups in their analyses. With important exceptions (e.g., Kazin 1998; Formisano 2008), American scholars find it hard to escape the attraction of using the

\footnotetext{
${ }^{10}$ For example, scholars are divided on whether to include Jobbik in Hungary and the Golden Dawn in Greece into the populist radical right party family. The same is true for Norway's Freedom Party.
} 
People's Party as their yardstick for all things populist. Students of Latin American populism are infatuated with charismatic personalities enjoying the unrestrained trust and support of unorganized popular masses. European scholars have developed their own tunnel vision, treating populism as identical with the far right. Since the mid-1990s, the empirical literatures on US, Latin American, and European populisms are advancing in parallel, with no effort put into resolving these glaring conceptual tensions. The unsuspicious observer would be tempted to surmise that they are discussing altogether different phenomena. The next section adds more substance to this verdict.

\section{The Policy Bias}

Political commentators_and even some academics-regularly associate populism with specific policies populists enact when in power that presumably lead to economic disaster. The bias in this line of reasoning is not so much about the spurious fit with empirical reality that will be illustrated below, but mainly with the fact that, in typically circular fashion, the association has been worked backwards from an effect to a condition, and from an inductive observation to a characteristic feature of populism. Economists working on Latin America in the 1970s and 1980s are the original perpetrators of this fallacious association that has since traveled far and wide and has become almost impossible to dislodge.

For decades, economists had been studying Latin America's economic development without reference to the conceptually alien notion of populism in their causal-theoretical models (e.g., Baer and Kerstenetzky 1964; ECLA 1950; Fliegers 1955; Mikesell 1960; Schulz 1956; Taylor 1953). The main trend had been a wave of protectionist policies that swept over most countries in the region, especially after the 1950s, known as Import Substitution Industrialization (ISI). A backlash against laissez-faire economics that had set the pace of reform in previous decades, ISI aimed at stimulating domestic demand through state intervention, protecting national industries from international competition by means of tariffs and excise taxes, and promoting national industrial "champions" that would stem the flow of imported goods from rich nations, thus ameliorating current account balances and even boosting foreign currency reserves through exports. Generally, governments (military or civilian) that opted for ISI achieved considerable growth and provided employment and increased wages to their citizens, but all to the long-term detriment of their economies, since growth was predicated on increasing levels of public debt that became unsustainable during the 1980s.

A semantic transformation emerged in the 1970s. Established concepts such as protectionism, statism, Keynesianism, dirigisme, or economic nationalism, employed until then to denote dominant modes of Latin American policy-making, gradually lost ground to what was termed "economic populism". The origins of this transformation are traced to 1971 when Cardoso and Faletto (1979) wrote of the ideology of "developmentalist populism" that accompanied the ISI phase under the intellectual influence of Raúl Prebisch (the "Latin American Keynes") and other structuralist theorists. Coupled with O'Donnell's (1973) influential analysis of "the 
populist period" in Brazil and Argentina and "populist authoritarianism" in Peru, Bolivia, and Ecuador, populism was steadily established as an economic notion, in effect equated with protectionism, state-driven industrialization, and domestic market expansion. Populism also assumed causal electoral implications: the (largely urban) social coalition that benefitted economically from ISI was seen as prone to maximize its utility by voting populist actors into office.

Populism served a career as a synonym for ISI until the late 1970s, when protectionist policies started to unwind. However, it curiously retained its relevance in the economic vocabulary even after ISI's demise and the subsequent domination of the so-called "Washington consensus". By means of another semantic shift, it was employed to qualify a subsequent wave of unorthodox policies (unrelated to ISI) that several Latin American leaders adopted in reaction to the 1980s' sovereign debt crisis. Two widely read working papers authored for the US National Bureau of Economic Development by Jeffrey Sachs (1989) and Dornbusch and Edwards (1989) repackaged economic populism as "an approach to economics that emphasizes growth and income redistribution and deemphasizes the risks of inflation and deficit finance, external constraints, and the reaction of economic agents to aggressive nonmarket policies" (Dornbusch and Edwards 1989, p. 1).

Populism was now equated tout court with "deficit spending" and "fiscal laxity," and it was implicitly assumed that all populist leaders engaged in unorthodox economics. Their actions, "characterized by overly expansionary macroeconomic policies which lead to high inflation and severe balance of payments crises" (Sachs 1989 , p. 5), spurred the infamous "populist policy cycle" in the domestic economy. The cycle purportedly starts with a short spike of economic growth and high expectations, quickly leading to severe bottlenecks, a reduction in real wages, hyperinflation, and eventually some form of bankruptcy and debt restructuring (Sachs 1989). Apart from its contemporary applications, the framework was retroactively applied back into the 1940s, and hence, from a Keynesian approach to promoting growth through ISI, populism became associated with destructive economic policies that lead to hyperinflation, the erosion of foreign currency reserves, domestic currency collapse, and bankruptcy.

The Latin American "pink tide" around the start of the twentieth century rejuvenated the theme. Castaneda's (2006) authoritative Foreign Affairs article emphasized the role of economic policy in distinguishing between the "right" (nonpopulist) left and the "wrong" (populist) left. The former type was employed to qualify leaders such as Lula in Brazil and the left-wing regimes in Chile and Uruguay, and generally implied some level of adherence to free-market principles. The populist left was associated in turn with Chavez in Venezuela, Lopez Obrador in Mexico, and Morales in Bolivia, who purportedly opted for nationalization of key industries, government handouts to the poor, and a general disregard for sound economics. Edwards (2010, p. 7) insisted that populists "used nationalistic and egalitarian rhetoric to justify increases in protectionism; harassment of foreign investors and businesses; nationalization of foreign companies; taxation of exports at almost expropriatory rates; hikes in regulations, red tape, and bureaucracy; and increases in the power of the executive branch of Latin American governments". 
The preceding paragraphs summarized the various mutations of the policy bias since the 1970s, a process that has left the theory of "economic populism" conveniently vague. However, and despite its continuing popularity, "economic populism" suffers from both methodological and empirical inconsistencies. First of all, there are issues of causal sequencing that resemble what we observed in the case of the regional bias. Economic policy can only be used as a yardstick to classify populist parties or leaders after they actually manage to win power and enact their policies. After all, the "populist cycle" is an outcomes-based, long-term theoretical framework: it is the results of enacted policies that purportedly vindicate the theory. Hence, the vast landscape of political parties that mobilize without ever getting the chance to actually govern is lost from our radar. There can be no populism in opposition. We have to wait, again, until Beppe Grillo wins the Italian national election, forms a government, passes his first economic bills, and an adequate body of statistical data on inflation, current account balances, and sovereign debt levels become public, before we can begin to form an opinion on whether Grillo is a populist. Similarly, we have to stand by until Donald Trump kicks the populist cycle into motion, all the way to the eventual bankruptcy of the American state, before we register him as a populist.

Secondly, the theory suffers at an empirical level. In hindsight, the "pink tide" did not prove destructive for Latin American economies. With the exception of Venezuela, the other members of the "tide" did not fare as bad as the paradigm predicted. Bolivians, for instance, have been enjoying a stable economic environment during Morales's long rule (Brienen 2016). While in 2005, their GDP per capita had sunk near its 1981 levels, their average annual return has tripled since MAS took office. ${ }^{11}$ The latest Article IV Consultation with the IMF commends Bolivia for achieving consistently robust growth rates, applauds the soundness of the financial sector, and praises the authorities "for the significant declines in inequality and poverty achieved over the last decade" (IMF 2016). Similarly, the IMF's 2015 Consultation with Correa's Ecuador finds that growth averaged $4.5 \%$ since 2005 and that social indicators improved during that decade, with both poverty and unemployment rates declining substantially (IMF 2015). Even the Argentinian economy overperformed after 2003, registering an average GDP growth of $4.6 \%$ during the thirteen years the Kirchners were in power, ${ }^{12}$ disproving the apocalyptic scenarios that circulated after their original victory (Panizza 2014). Fiscal performance is an easily monitored dependent variable that opens large holes in the conceptual foundations of "economic populism". A simplistic reductio ad Venezuelanum, singling out Chavismo as the epitome of populist catastrophe, cannot rescue the theory from criticism.

The policy bias is also at odds with empirical evidence from populist governance in Europe. Right-wing populist parties have won power, joined governing coalitions, or supported minority governments in Europe in the past three decades - such as with FIDESZ in Hungary, the coalition governments involving Forza Italia and the Lega Nord in Italy, the FPÖ and the BZÖ in Austria, SVP in

\footnotetext{
11 Source: World Bank (http://data.worldbank.org).

12 Source: World Bank (http://data.worldbank.org).
} 
Switzerland, the Finns in Finland, the Norwegian Freedom Party, the PVV and Lijst Pim Fortuyn in the Netherlands, the HZDS in Slovakia, and PiS in Poland-yet no "populist cycle" materialized. On the contrary, considerable growth was achieved in many cases. Besides, Western European populist parties of the right had consistently campaigned in favor of fiscal orthodoxy since the 1980s, to the point that scholars saw neoliberalism as a key element of the "winning formula" that rendered them successful in the first place (Kitschelt 1995).

The "populist policy cycle" did not materialize in Europe even under left-wing populists that resemble the Latin American paradigm more closely. Smer has ruled Slovakia since $2006,{ }^{13}$ and Greece has been run by a government coalition under a left-wing populist party since 2015 . Yet, in both cases, governments have generally adhered to the guidelines of international financial organizations, with Greece even managing to achieve an unprecedented primary surplus, checking almost every box in the list of fiscally orthodox reforms. Outside Europe, the case of Shinawatra's Thai Rak Thai Party was another instance of a healthy economy under populist rule, and so was Canada under Stephen Harper and Australia under John Howard (Snow and Moffitt 2012). Should we, succumbing to the policy bias, retract the populist qualification from all these famous cases?

So far, it seems that a strict adherence to the "populist cycle" as the necessary and sufficient characteristic of populism leaves as with very few instances of populism throughout global history since it excludes all parties in opposition and all those leaders who failed to plunge their domestic economies into catastrophe during their tenure. But perhaps the paradigm can be saved by switching to a new theory of "economic populism" that prioritizes electoral promises over economic performance, programmatic statements on economic policy-making over monitoring solid policy outcomes. In this case, we should expect empirical scrutiny to rely on complex econometric models that predict whether the various electoral platforms will eventually lead to a "populist cycle" and a bankrupt economy if enacted in office.

Setting aside the technical feasibility of such evaluations, this-yet to be formulated theory-would also have a hard time classifying "bait-and-switch" politicians. There is a long history of this kind of behavior on the part of Latin American leaders, who reneged on their promises to enact expansionary policies and betrayed their mandates by embracing free-market reforms once in office (Stokes 2001). By the time Dornbusch and Edwards (1991) published their influential volume on economic populism, the Cold War had ended and expansionist policies had generally fallen out of vogue. Latin American Presidents such as Fujimori in Peru, Collor in Brazil, and Menem in Argentina-widely registered as populistshad turned into enthusiastic proponents of orthodox economics, fiscal consolidation, privatization, and deregulation. The results of their policies were a far cry from the "populist cycle". Guided by these developments, influential scholars of Latin American populism such as Roberts (1995) and Weyland (1996) decided to break ranks with economists and not only to dismiss profligate economic policy as a

${ }^{13}$ Except for 2010-2012. 
defining characteristic of populism but also to argue persuasively that neoliberalism had always been perfectly compatible with populism.

Even if one disagrees with the choice to uphold populism as a "purely political concept" (Weyland 1996, p. 6), the question remains: how should we classify "baitand-switch" cases? Are they populists when they overpromise and cease to be so right after they switch to orthodox policies? Or is it somehow justified to retain the populist label for them just because of their prior record? If one of the pitfalls in the first version of the theory of "economic populism" was that it left us with only a small number of cases where the "populist cycle" was at work, the second version produces the opposite problem. If populism is merely overpromising, then it would be difficult to find any political party that does not campaign on populist grounds. ${ }^{14}$

Despite the avalanche of methodological inconsistencies and empirical falsifications, scholars of populism need to constantly remain vigilant against its degradation to an economic term. Brexit, and the populist overtones of the recent US Presidential primaries, where both Donald Trump, on the side of the Republican Party, and Bernie Sanders, on the part of the Democratic Party, entertained economic ideas that seemed at a distance from the mainstream, brought the theme of "economic populism" once more to the fore. Today, most political commentators are going as far as dismissing any type of economic policy not predicated upon a balanced budget as populist. The number of policy papers and editorials that equate populism with destructive economic policies has grown enormously. For instance, in an article titled "How Economic Populism Works", the former finance minister of Chile posits that "there can be no disagreement that Latin Americans have been the longest and best practitioners of economic populism" (Velasco 2017), cherrypicking Peron, Vargas, Garcia ("at least during his first term"), Ortega, and Allende, as exemplary cases, mixing-and-matching ISI, socialism, authoritarianism, and Keynesianism, and avoiding mention of all those cases that escape the paradigm. Similarly, the Council on Foreign Relations dedicated its December 2015 Global Economics Monthly to the issue of "Addressing Economic Populism in Europe" (Kahn 2015), while De Bolle (2016), citing Dornbusch and Edwards (1991), applied the "populist paradigm" to contemporary Brazil, dismissing the country's stellar economic performance in the last decade.

Even if one is not ready to concede that populism bears no links to economic policy, it is still helpful at this point to compare the "economic populism" paradigm with the different conceptualizations of populism discussed earlier. Understanding populism as a destructive type of economic policy-making, seeing it as a core feature of far right parties, and associating it with the activity of an all-powerful leftwing leader that leads unorganized masses to power are hardly mutually compatible positions. On the contrary, conceptual and methodological degrees of separation appear overwhelming. Nevertheless, pundits and analysts will frequently prioritize ends over means and will readily engage in mixing-and-matching these otherwise irreconcilable perspectives. As I argue in the next section, this haphazard behavior is not always a simple artifact of a pronounced tolerance for ambiguity.

\footnotetext{
14 Another dangerous implication of the policy bias is to end up classifying as populist any party that stands in favor of some kind of redistribution.
} 


\section{The Normative Bias}

Scholars of populism have done much to lend a profligate nature to their concept, as shown in the previous sections. Pundits and politicians have also greatly contributed to turning populism into a political buzzword. The term has now mainly acquired a pejorative sense, and its various negative angles - the links to extremism, the irrational approach to economics, the authoritarian elements of personalism-converge towards conceiving populism as a menace to liberal democracy (Urbinati 2014; Pappas 2016). Populism is considered an ideology, a set of values, or a regime, that stands opposite to a liberal democratic paradigm because of a tendency to bend the rule of law, disrespect the separation of powers, disrupt the free market, and display hostility against minorities. This highly normative context influences the analytical study of populism since scholars find it difficult to distance their work from the tacit expectation of taking a position in an ongoing ideological battle. Political shocks such as Brexit, the rise of Donald Trump to the US Presidency, and a general electoral upsurge of populist parties, have intensified polarization in the public sphere, tempting academics to use their analytical tools in the service of wider political aims, linking their findings to an increasing journalistic demand for political commentary on populism's purported ascendance.

Loading an analytical term with normative content to the point of transforming it into a political tool is not peculiar to populism. As Brubaker (2004) explains with regards to the study of nationalism, scholars do not only observe politics but occasionally participate in political struggle. Hence, the felt need to differentiate between various types of nationalism and attach moral prestige to the well-known notion of "civic" (as opposed to "ethnic") nationalism may have originated with a project that is "more political than analytical: it may speak more to the putative international respectability and legitimacy of the state or movement in question than to its empirical characteristics" (Brubaker 2004, p. 135). A term loaded by definition with negative connotations becomes a useful stick to beat political opponents: "Who could have a good word for a form of nationalism routinely glossed as illiberal, ascriptive, and exclusive?" (Brubaker 2004, p. 135).

Brubaker's analysis bears a striking resemblance to the ideological battle simmering among academics of different ideological origins in populism studies. Yet, the politicization of populism is not a new phenomenon. On the contrary, it carries a long and quite distinct history. When the McCarthyist revolt spurred terror and disgust among the ranks of pluralist American academics in the 1950s, populism was-for the first time-uprooted from its historical context to be employed as the thread that linked together all instances of "paranoid" politics in American history (Saloutos 1966; Rogin 1967). As Edward Shils (1956, p. 103) suggested, "[t]here is a straight line from Ben Tillman to Huey Long and Eugene Talmadge; from Bryan and LaFollette to Gerald L. K. Smith, Father Coughlin and Senator McCarthy, Gerald Nye, William Langer and many others." A speech by Shils in 1954 at the University of Chicago (Allcock 1971) and two influential volumes published in the following year, Richard Hofstadter's The Age of Reform (1955) and Daniel Bell's The New American Right (1955), proved pivotal in recasting the populist movement of the $1880 \mathrm{~s}-90$ s as a dark and irrational force, a 
direct progenitor of every anti-liberal strand in American society that subsequently found its national representative in Senator McCarthy. ${ }^{15}$ Some went even further, drawing a direct link between Populism and American fascism (Ferkiss 1957). ${ }^{16}$

The emotions of shame and despair that McCarthyism spread within academic circles acted as the crucial trigger that transformed populism from a historical to a political-analytical concept in the mid-1950s. ${ }^{17}$ Even if important enemies of this revisionist drive such as Pollack (1960) and Nugent (1963) exaggerated in their critique, Hofstadter certainly overplayed his hand to make a normative point, as he later conceded to several of his colleagues (Collins 1989; Stavrakakis 2017). The recasting of populism as an anti-liberal mentality in the work of modernization theorists had an immense impact that reverberates until today and partly explains its haphazard use. The catch-all nature of populist mobilization and its tentative relationship with liberal democratic values render it a political instrument that can cut both ways, in favor of those who like to see it as a radical yet progressive movement, but also those who tend to emphasize its darker implications (Rovira Kaltwasser 2012). ${ }^{18}$

Liberal theorists today will caution that populist movements present a danger for core elements of our liberal democracies. Populist leaders distort the playing field and employ plebiscitary methods that undermine representative institutions and have the capacity to disfigure democracy and lead societies down authoritarian avenues (Urbinati 2014). They mobilize "an exclusionary form of identity politics" (Müller 2016, p. 3) that erodes pluralist values, colonizes the state apparatus, favors mass clientelism, and fosters corruption. The populists' claim to be democrats is fake since their view of democracy is a distorted one that, if implemented, will ultimately dismantle our institutions and establish a totalitarian state of affairs.

On the other side, radical democratic theorists will distinguish between "phony populists" who hide their authoritarianism behind a seemingly democratic façade, and those true populists who do nothing but reclaim the values of popular sovereignty, political freedom, and equality, core democratic tenets that have been increasingly receding in our post-democratic times. They will point out that skepticism towards elites is a healthy element in democratic societies (McCormick

\footnotetext{
15 Another very influential volume of the same school is Lipset's (1960) Political Man, where, under "Chapter V: Fascism-Left, Right, and Center" we find a subsection titled "The United States: McCarthyism as Populist Extremism".

16 As Pollack (1967) attests, while Hofstadter (1955) and Bell (1955) were the ones who introduced this pejorative revisionism to the wider public, the seeds had been sown in academic circles earlier, when Handlin (1951) linked the rise of anti-semitism in America to the legacy of the People's Party (see also Ferkiss 1954).

17 Of course, this only pertains to the Western world. The legacy of the narodniki movement informed an equally interesting attack on the part of orthodox Marxist intellectuals who were probably the first ones to use the term in a strategically pejorative manner, smearing as "populists" those within the socialist camp who believed that socialism could be established without a passage through capitalism. Lenin also criticized the populist mentality from a vanguardist point of view, even though he did acknowledge several positive elements in the narodniki (see Brock 1961).

18 For a comprehensive analysis of the impact of modernization theory on populism, see Stavrakakis (2017), Jäger (2017), D’ Eramo (2013), and Abbott (2007).
} 
2001) and that citizens are justified in being vigilant against elites with regards to the power struggle over issues that dominate the decision-making process. They will emphasize limitations in the juridical view of democracy and claim that people are allowed to question power-holding institutions when the latter contribute to an overly rigid accommodation of popular sovereignty. In this sense, they will uphold populism as a legitimate tradition with a "persistent democratizing aspiration" (Grattan 2016, p. 10).

A major misconception that feeds into the polarization between the two contrasting views is the persistent use of populism as a dichotomous term, despite the battery of empirical work that proves its graded nature (Aslanidis 2017; Bonikowski and Gidron 2016; Hawkins 2010; Rooduijn and Pauwels 2011). Populism, as a language, is employed to various degrees by a large majority of politicians, making it hard to straightforwardly divide them into populists and non-populists. ${ }^{19}$ However, populism's "demotion" to a matter of degree rather than kind would devalue its assumed political import, rendering it a blunt instrument for use within the Manichean field of political struggle. Academic experts who are able to publicly furnish arguments from authority over whether politician X or Y is indeed "a populist," gain significant mediatic currency, functioning as epistemic gatekeepers of the concept and providing a veneer of scientific legitimation for normative political claims. In a volatile political environment ripe with outsider contenders, this behavior deterministically leads to a significant expansion of the concept's application. As Mudde and Rovira Kaltwasser (2012, p. 1) complain, "it seems that almost every politician, at least those we do not like, is a populist".

This highly politicized backdrop influences the quality of academic work, dividing scholars into those who see populism in a positive light and those who see it negatively (Rovira Kaltwasser 2012). Unable to distance themselves from the normative connotations of populism, and faced with the task of assessing a specific phenomenon as populist or non-populist, researchers may be tempted to work backwards, beginning with gauging their personal emotions towards the movement, political party, or leader, under consideration, before devising an analytical framework to accommodate their stance. In essence, there is a four-fold typology of normative bias, along two interrelated questions. Combining their positions on whether they sympathize with populism in general and whether they favor the particular case (political party, leader, movement etc.) they are analyzing, researchers adopt one out of four resulting perspectives: if the researcher is sympathetic to both populism and the case she is studying, the tendency will be to enthusiastically endorse the populist nature of the latter; if she subscribes to a negative view of populism, she will step in to rescue the case from the populist accusation. In contrast, a negative stance on both accounts will lead to a straightforward denunciation of the case as a dangerous populist phenomenon. And in the-not so rare-event that a negative stance against the case under consideration coincides with positive feelings for populism in general, the

\footnotetext{
${ }_{19}$ Peter Mair (2002), for instance, has famously studied Tony Blair's populism.
} 
researcher will make every effort to prove that the case should not be classified as populist. $^{20}$

The normative bias starts with the conscious use of the "populist" epithet as a valence, a normative signal denoting a "good" or "bad" politician. Yet in both cases, the problem is that populism has been infused with immense and unwarranted causal implications for democratic governance. Both camps inflate populism's significance for their desired set of policies. However, there is no straightforward path from observing the use of populist discourse by a given politician to deriving conclusions about her ultimate performance in government. A rhetorical adherence to the value of popular sovereignty and a distaste towards the power of elites may prove a powerful act in terms of electoral mobilization but it cannot readily supply information about deeper ideological anchors entertained by a given politician and it is a weak predictor of actual policy preference. As Mudde and Rovira Kaltwasser (2012) explain, a populist's record in government will have more to do with her main ideological or attitudinal inclinations (right-wing, left-wing, libertarian, authoritarian), rather than the impact of the populist invocations employed to attract wider support for a political project. In this light, Fukuyama (2016, p. 68) cautions that populism may end up an empty label that "political elites attach to policies supported by ordinary citizens that they don't like" and advises that populist mobilizations should be understood as "neither inherently bad nor inherently good; they can do great things, as during the Progressive era and the New Deal, but also terrible ones, as in Europe during the 1930s."

\section{Conclusion}

Populism is a relatively widespread political phenomenon. In any type of regime, the public may grow apprehensive of power-holding elites that tend to maximize their personal utility at the expense of other actors or groups. Whether elite manipulation actually takes place or not, and to what level, is irrelevant; what matters is that in those countries where political contestation is institutionalized or becomes marginally available for whatever reasons, political actors with a credible outsider status will tend to mobilize grievances by use of a populist language as an entry point into the hearts and minds of the citizens. When citizens feel overly alienated against elites, due to perceived policy failures of the latter, or issues of corruption, or simply boredom with a stagnated state of intellectual affairs, the populist message will tend to gather steam.

Therefore, whether the populists' attacks against elites reflect an underlying reality and whether their actions in office are going to prove negative for the economy or the quality of democratic contestation, should be seen as open, empirical questions. The schemata that politicians employ to frame their arguments provide little evidence for their actual political views and policy inclinations and should not be taken as determined outcomes. Instead of stipulating non-existent

\footnotetext{
${ }^{20}$ See for instance the interestingly different appraisals of the Tea Party by Charles Postel and Chip Berlet in Rosenthal and Trost (2012).
} 
patterns or generalizing from characteristics that only pertain to specific instances of populism, researchers should consider a wider set of factors when assessing the record of politicians to whom the label is attached. When, for instance, nationalist politicians employ populist language alongside their main ideas about the interests of a national society, populism tells us little about the core tenets of their behavior. The same is true for socialist politicians who otherwise mobilize voters along class lines.

Populism's flexible nature opens the door for all sorts of generalizations, yet researchers should avoid the biases analyzed in this paper if the analytical utility of the concept is to be cured of its currently overstretched status. Populism should not necessarily connote charismatic leaders who win presidential seats by mobilizing unorganized masses: populist voters can be organized into well-functioning parties, personalism or strong leadership may be absent, populist parties may survive as marginal actors in multiparty parliamentary systems, and populism can even emerge as a leaderless social movement rather than a party. Populism is not a fixture of the far right: nationalists may color their discourse with populism elements, or they may not, and populism can be mobilized without any connection to nationalist, xenophobic, or racist rhetoric. There is no established link between populism and specific economic policies: populists may bankrupt their states but they can also lead them to stability and prosperity, or they may choose between expansionary and conservative economic policies according to their strategic calculations, like every other rational politician. The relationship between populism and democracy should not be overstated: depending on the case, populists may bend liberal institutions and undermine political contestation, but they may also lead to a restoration of democratic accountability and an increased involvement of previously unrepresented social groups - and all this may have little to do with the populist discourse that helped a party win power in the first place.

Overcoming the pitfalls of the regional bias, the policy bias, and the normative bias, requires a process of unlearning. Prospective students of populism need to first unlearn the misconceptions with which they were introduced to the concept, before they can approach its true nature. Populism is a handy tool for anti-establishment forces looking to open up cracks in established party systems but also for mainstream forces that use anti-populism to discredit their legitimate opponents. The field is at a critical juncture today: it will either succumb to populism's instrumental use for partisan politics and suffer its subsequent erosion as a scientific term, or it will become more rigorous and objective in its assessments and resist sensationalist temptations. Scholars of populism need not become fodder in this political battle.

\section{References}

Abbott, Philip. 2007. "Bryan, Bryan, Bryan": Democratic theory, populism, and Philip Roth's “American Trilogy”. Canadian Review of American Studies 37 (3): 431-452.

Allcock, J.B. 1971. "Populism": a brief biography. Sociology 5 (3): 371-387. 
Aslanidis, Paris. 2016a. Is populism an ideology? A refutation and a new perspective. Political Studies 64 (IS): $88-104$

Aslanidis, Paris. 2016b. Populist social movements of the great recession. Mobilization: An International Journal 21 (3): 301-321.

Aslanidis, Paris. 2017. Measuring populist discourse with semantic text analysis: an application on grassroots populist mobilization. Quality \& Quantity. doi:10.1007/s11135-017-0517-4.

Baer, Werner, and Isaac Kerstenetzky (eds.). 1964. Inflation and growth in Latin America. New Haven: Yale University Press.

Bell, Daniel (ed.). 1955. The new American right. New York: Criterion Books.

Betz, Hans-Georg. 1990. Politics of resentment: right-wing radicalism in West Germany. Comparative Politics 23 (1): 45-60.

Betz, Hans-Georg. 1993. The new politics of resentment: radical right-wing populist parties in Western Europe. Comparative Politics 25 (4): 413-427.

Betz, Hans-Georg. 1994. Radical right-wing populism in Western Europe. New York: St Martin's Press.

Betz, Hans-Georg. 2002. Conditions favoring the success and failure of radical right-wing populist parties in contemporary democracies. In Democracies and the populist challenge, ed. Yves Mény, and Yves Surel, 197-213. London: Palgrave Macmillan.

Bonikowski, Bart, and Noam Gidron. 2016. The populist style in American politics: presidential campaign discourse, 1952-1996. Social Forces 94 (4): 1593-1621.

Brienen, Marten. 2016. A populism of indignities: Bolivian populism under Evo Morales. The Brown Journal of World Affairs 13 (1): 77-92.

Brock, Peter. 1961. The Polish "movement to the People": an early chapter in the history of East European populism. The Slavonic and East European Review 40 (94): 99-122.

Brubaker, Rogers. 2004. Ethnicity without groups. Cambridge: Harvard University Press.

Canovan, Margaret. 2005. The people. Cambridge: Polity Press.

Caramani, Daniele. 2017. Will vs. reason: the populist and technocratic forms of political representation and their critique to party government. American Political Science Review 111 (1): 54-67.

Cardoso, Fernando Henrique, and Enzo Faletto. 1979. Dependency and development in Latin America. Berkeley: University of California Press.

Carter, Elisabeth. 2005. The extreme right in Western Europe: success or failure? Manchester: Manchester University Press.

Castañeda, Jorge G. 2006. Latin America's left turn. Foreign Affairs 85 (3): 28-43.

Collins, Robert M. 1989. The originality trap: Richard Hofstadter on populism. The Journal of American History 76 (1): 150-167.

Conniff, Michael L. 2012. Introduction. In Populism in Latin America, 2nd ed, ed. Michael L. Conniff, 1-22. Tuscaloosa: The University of Alabama Press.

de Bolle, Monica. 2016. More lessons from Brazil's boom-bust: the "populist paradigm" revisited. Peterson Institute for International Economics, 14 December 2016. https://piie.com/blogs/realtimeeconomic-issues-watch/more-lessons-brazils-boom-bust-populist-paradigm-revisited. Accessed 29 May 2017.

D'Eramo, Marco. 2013. Populism and the new oligarchy. New Left Review 82 (July-August): 5-28.

Di Tella, Torcuato S. 1965. Populism and reform in Latin America. In Obstacles to change in Latin America, ed. Claudio Veliz, 47-74. London: Oxford University Press.

Dornbusch, Rudiger, and Sebastian Edwards (eds.). 1991. The macroeconomics of populism in Latin America. Chicago: University of Chicago Press.

Dornbusch, Rudiger, and Sebastian Edwards. 1989. Macroeconomic populism in Latin America. Working Paper No. 2986. Cambridge, MA: National Bureau of Economic Development.

ECLA. 1950. The economic development of latin america and its principal problems. United Nations Department of Economic Affairs. New York: Economic Commission for Latin America.

Edwards, Sebastian. 2010. Left behind: Latin America and the false promise of populism. Chicago: University of Chicago Press.

Falter, Jürgen W., and Siegfried Schumann. 1988. Affinity towards right-wing extremism in Western Europe. West European Politics 11 (2): 96-110.

Ferkiss, Victor C. 1957. Populist influences on American Fascism. The Western Political Quarterly 10 (2): $350-373$.

Ferkiss, Victor C. 1954. The political and economic philosophy of American Fascism. Unpublished dissertation. Department of Political Science, University of Chicago. 
Fliegers, Serge. 1955. The financing of Latin America's economic development. Journal of International Affairs 9 (1): 56-63.

Formisano, Ronald P. 2008. For the people: American populist movements from the revolution to the 1850s. Chapel Hill: The University of North Carolina Press.

Fukuyama, Francis. 2016. American political decay or renewal? The meaning of the 2016 election. Foreign Affairs 95 (4): 58-68.

Gerbaudo, Paolo. 2017. The mask and the flag: populism, citizenism and global protest. New York: Oxford University Press.

Grattan, Laura. 2016. Populism's power: radical grassroots democracy in America. Oxford: Oxford University Press.

Handlin, Oscar. 1951. American views of the Jew at the opening of the twentieth century. Publications of the American Jewish Historical Society 40 (4): 323-344.

Harris, Geoff. 1990. The dark side of Europe: the extreme right today. Edinburgh: Edinburgh University Press.

Hawkins, Kirk A. 2010. Venezuela's chavismo and populism in comparative perspective. Cambridge: Cambridge University Press.

Hofstadter, Richard. 1955. The age of reform: from Bryan to F.D.R. London: Jonathan Cape.

Horowitz, Joel. 2012. Populism and its legacies in Argentina. In Populism in Latin America, 2nd ed, ed. Michael L. Conniff, 23-47. Tuscaloosa: The University of Alabama Press.

Husbands, Christopher T. 1981. Contemporary right-wing extremism in Western European democracies: a review article. European Journal of Political Research 9 (1): 75-99.

Ignazi, Piero. 2003. Extreme right parties in Western Europe. Oxford: Oxford University Press.

Ignazi, Piero. 1992. The silent counter-revolution: hypotheses on the emergence of extreme right-wing parties in Europe. European Journal of Political Research 22 (1): 3-34.

IMF. 2015. Ecuador: 2015 Article IV consultation-IMF Country Report No. 15/289. Washington, DC: International Monetary Fund.

IMF. 2016. Bolivia: 2016 Article IV consultation-IMF Country Report No. 16/387. Washington, DC: International Monetary Fund.

Inglehart, Ronald F., and Pippa Norris. 2016. Trump, Brexit, and the rise of populism: economic havenots and cultural backlash, Faculty Research Working Paper Series RWP16-026. Cambridge, MA: Harvard Kennedy School, John F. Kennedy School of Government.

Jäger, Anton. 2017. The semantic drift: images of populism in post-war American historiography and their relevance for (European) political science." Forthcoming in Constellations.

Jagers, Jan, and Stefaan Walgrave. 2007. Populism as political communication style: an empirical study of political parties' discourse in Belgium. European Journal of Political Research 46 (3): 319-345.

Kahn, Robert. 2015. Addressing economic populism in Europe: global economics monthly, December 2015. Washington, D.C.: Council on Foreign Relations, Center for Geoeconomic Studies. https:// www.cfr.org/sites/default/files/pdf/2015/12/December\%202015\%20GEM.pdf. Accessed 29 May 2017.

Kazin, Michael. 1998. The populist persuasion: an American history (revised edition). Ithaca: Cornell University Press.

Kitschelt, Herbert. 1995. The radical right in Western Europe: a comparative analysis. Ann Arbor: Michigan University Press.

Laclau, Ernesto. 2005. On populist reason. London: Verso.

Levitsky, Steven, and James Loxton. 2013. Populism and competitive authoritarianism in the Andes. Democratization 20 (1): 107-136.

Lipset, Seymour Martin. 1960. Political man: the social bases of politics. New York: Doubleday \& Company.

Mair, Peter. 2002. Populist democracy vs party democracy. In Democracies and the populist challenge, ed. Yves Mény, and Yves Surel, 81-98. Basingstoke: Palgrave Macmillan.

McCormick, John P. 2001. Machiavellian democracy: controlling elites with ferocious populism. American Political Science Review 95 (2): 297-313.

Mény, Yves, and Yves Surel. 2002. The constitutive ambiguity of populism. In Democracies and the populist challenge, ed. Yves Mény, and Yves Surel, 1-21. Basingstoke: Palgrave Macmillan.

Mikesell, Raymond F. 1960. Latin American economic development: some basic issues. Journal of International Affairs 14 (2): 126-139.

Minkenberg, Michael. 2013. From pariah to policy-maker? The radical right in Europe, West and East: between margin and mainstream. Journal of Contemporary European Studies 21 (1): 5-24. 
Minkenberg, Michael. 2015. Profiles, patterns, process: studying the East European radical right in its political environment. In Transforming the transformation? The East European radical right in the political process, ed. Michael Minkenberg, 27-56. Oxon: Routledge.

Moffitt, Benjamin. 2016. The global rise of populism: performance, political style, and representation. Stanford: Stanford University Press.

Mudde, Cas. 2004. The populist zeitgeist. Government and Opposition 39 (4): 542-563.

Mudde, Cas. 2007. Populist radical right parties in Europe. Cambridge: Cambridge University Press.

Mudde, Cas. 2013. Three decades of populist radical right parties in Western Europe: so what? European Journal of Political Research 52 (1): 1-19.

Mudde, Cas, and Cristóbal Rovira Kaltwasser. 2012. Populism and (liberal) democracy: a framework for analysis. In Populism in Europe and the Americas: threat or corrective for democracy?, ed. Cas Mudde, and Cristóbal Rovira Kaltwasser, 1-26. Cambridge: Cambridge University Press.

Müller, Jan-Werner. 2016. What is populism? Philadelphia: University of Pennsylvania Press.

Norris, Pippa. 2005. Radical right: voters and parties in the electoral market. Cambridge: Cambridge University Press.

Nugent, Walter T.K. 1963. The tolerant populists: Kansas populism and nativism. Chicago: The University of Chicago Press.

O’Donnell, Guillermo. 1973. Modernization and bureaucratic-authoritarianism: studies in South American politics. Berkeley: University of California Press.

Panizza, Francisco. 2014. "Everybody out", "we are fantastic:" the politics of financial crises in Argentina and Uruguay 2001-2003. In Moments of truth: the politics of financial crises in comparative perspective, ed. Francisco Panizza, and George Philip, 27-46. New York: Routledge.

Pappas, Takis S. 2016. The specter haunting Europe: distinguishing liberal democracy's challengers. Journal of Democracy 27 (4): 22-36.

Pollack, Norman. 1960. Hofstadter on populism: a critique of "the age of reform". The Journal of Southern History 26 (4): 478-500.

Pollack, Norman. 1962. The populist response to industrial America. Cambridge: Harvard University Press.

Pollack, Norman (ed.). 1967. The populist mind. Indianapolis: The Bobbs-Merrill Company Inc.

Postel, Charles. 2012a. The Tea Party in historical perspective: a conservative response to a crisis of political economy. In Steep: the precipitous rise of the Tea Party, ed. Lawrence Rosenthal, and Christine Trost, 25-46. Berkeley: University of California Press.

Postel, Charles. 2012b. Occupy: a populist response to the crisis of inequality. Mittelweg 36 (5).

Roberts, Kenneth M. 1995. Neoliberalism and the transformation of populism in Latin America: the Peruvian case. World Politics 48 (1): 82-116.

Roberts, Kenneth. 2012. Preface. In Populism in Latin America (second edition), ed. Michael L. conniff, ix-x. Tuscaloosa: The University of Alabama Press.

Roberts, Kenneth M. 2015. Populism, social movements, and popular subjectivity. In The Oxford handbook of social movements, ed. Donatella Della Porta, and Mario Diani, 681-695. Oxford: Oxford University Press.

Rogin, Michael Paul. 1967. The intellectuals and McCarthy: the radical specter. Cambridge: The M.I.T. Press.

Rooduijn, Matthijs, and Teun Pauwels. 2011. Measuring populism: comparing two methods of content analysis. West European Politics 34 (6): 1272-1283.

Rosenthal, Lawrence, and Christine Trost. 2012. Steep: the precipitous rise of the Tea Party. Berkeley: University of California Press.

Rovira Kaltwasser, Cristóbal. 2012. The ambivalence of populism: threat and corrective for democracy. Democratization 19 (2): 184-208.

Sachs, Jeffrey D. 1989. Social conflict and populist policies in Latin America. Working Paper No. 2897. Cambridge, MA: National Bureau of Economic Development.

Saloutos, Theodore. 1966. The professors and the populists. Agricultural History 40 (4): 235-254.

Schultz, Theodore W. 1956. Latin-American economic policy lessons. The American Economic Review 46 (2): 425-432.

Shils, Edward A. 1956. The torment of secrecy: The background and consequences of American security policies. Glencoe: Free Press.

Snow, Dave, and Benjamin Moffitt. 2012. Straddling the divide: mainstream populism and conservatism in Howard's Australia and Harper's Canada. Commonwealth \& Comparative Politics 50 (3): 271-292. 
Stavrakakis, Yannis. 2017. How did "populism" become a pejorative concept? And why is this important today? A genealogy of double hermeneutics. Paper presented at the Populism in Theory: Towards an Anthropological Frame workshop, Universidad de Barcelona, January 10th-12th, 2017.

Stavrakakis, Yannis, and Giorgos Katsambekis. 2014. Left-wing populism in the European periphery: the case of SYRIZA. Journal of Political Ideologies 19 (2): 119-142.

Stavrakakis, Yannis, Giorgos Katsambekis, Nikos Nikisianis, Alexandros Kioupkiolis, and Thomas Siomos. 2017. Extreme right-wing populism in Europe: revisiting a reified association. Critical Discourse Studies. doi:10.1080/17405904.2017.1309325.

Stokes, Susan C. 2001. Mandates and democracy: neoliberalism by surprise in Latin America. New York: Cambridge University Press.

Taggart, Paul. 2000. Populism. Buckingham: Open University Press.

Taylor, Amos E. 1953. The economic development of Latin America. World Affairs 116 (1): 12-14.

Tindall, George B. 1972. Populism: a semantic identity crisis. The Virginia Quarterly Review 48 (4): 501-518.

Urbinati, Nadia. 2014. Democracy disfigured: opinion, truth, and the people. Cambridge: Harvard University Press.

Velasco, Andrés. 2017. How economic populism works. Project Syndicate, 7 February 2017. https:// www.project-syndicate.org/commentary/economic-populism-temporary-success-by-andres-velasco2017-02. Accessed 29 May 2017.

von Beyme, Klaus. 1988. Right-wing extremism in post-war Europe. West European Politics 11 (2): $1-18$.

Wear, Rae. 2008. Permanent populism: the howard government 1996-2007. Australian Journal of Political Science 43 (4): 617-634.

Weyland, Kurt. 1996. Neopopulism and neoliberalism in Latin America: unexpected affinities. Studies in Comparative International Development 31 (3): 3-31.

Weyland, Kurt. 2012. Populism in the age of neoliberalism. In Populism in Latin America, 2nd ed, ed. Michael L. Conniff, 201-222. Tuscaloosa: The University of Alabama Press.

Weyland, Kurt. 2013. The threat from the populist left. Journal of Democracy 24 (3): 18-32.

Woods, Dwayne. 2014. The many faces of populism: diverse but not disparate. In The many faces of populism: current perspectives, ed. Dwayne Woods, and Barbara Wejnert, 1-25. Brigley: Emerald Group Publishing Limited.

Paris Aslanidis is a Lecturer at the Department of Political Science and the Hellenic Studies Program at Yale University. He studies populism in social movements and political parties, with a particular interest in the quantification of populist discourse. His articles have been published in journals such as Political Studies, Mobilization, Democratization, and Quality \& Quantity. His chapter on "Populism and Social Movements" is under publication in the Oxford Handbook of Populism. 